\title{
Ursolic Acid Attenuates Renal Injury Induced by Adriamycin in Mice
}

\author{
Wenjun Gou, Te'an Ma, Qing Wu, Qingfeng Lei, Pan Zhang* \\ Department of Nephrology, First Affiliated Hospital of Yangtze University, Jingzhou, China \\ Email: *dzhangpan@126.com
}

How to cite this paper: Gou, W.J., Ma, T.A., Wu, Q., Lei, Q.F. and Zhang, P. (2019) Ursolic Acid Attenuates Renal Injury Induced by Adriamycin in Mice. Yangtze Medicine, 3, 261-270. https://doi.org/10.4236/ym.2019.34025

Received: January 25, 2019

Accepted: June 27, 2019

Published: June 30, 2019

Copyright (อ 2019 by author(s) and Scientific Research Publishing Inc. This work is licensed under the Creative Commons Attribution International License (CC BY 4.0).

http://creativecommons.org/licenses/by/4.0/ (c) (i) Open Access

\begin{abstract}
Objective: To explore the protective effects of ursolic acid (UA) on adriamycin nephropathy in mice. Methods: Totally 40 male Balb/c mice were randomly divided into normal group, model group, low dose of UA group and high dose of UA group. One-time injection of Adriamycin (ADR) at 10.0 $\mathrm{mg} / \mathrm{kg}$ via tail vein was used to establish the model. Different doses of UA were administered to the mice in treatment groups from the first day after successful modeling. After 3 consecutive weeks, $24 \mathrm{~h}$ urine protein was measured, and BUN, Scr and TG as well as SOD, MDA and GSH were also measured. The IL- $1 \beta$, TNF- $\alpha$ and TGF- $\beta 1$ were measured by ELISA; SMAD2/3 phosphorylation and its target protein $\alpha$-SMA expression were measured by Western Blot; pathological changes of renal tissues were observed. Results: Compared with the model group, UA can significantly reduce the urine protein, BUN, Scr, TG, MDA, IL- $1 \beta$, TNF- $\alpha$, TGF- $\beta$ and SMAD2/3 phosphorylation and its target protein $\alpha$-SMA expression while increasing the GSH and SOD, and the difference is significant $(\mathrm{P}<0.05)$. Conclusions: Ursolic acid can protect against renal damage by inhibiting oxidative stress and reducing the release of inflammatory cytokines, which may be related to the inhibition of TGF- $\beta 1 /$ Smads-related signaling pathway.
\end{abstract}

\section{Keywords}

Ursolic Acid, Adriamycin Nephropathy, TGF- $\beta$-Related Signaling Pathway, Mice

\section{Introduction}

Adriamycin nephropathy (AN), also known as doxorubicin nephropathy, is a classic model commonly used to simulate minimal change nephropathy (MCD) [1]. It is mainly because the adriamycin (ADR) causes lipid peroxidation of cell 
membrane, which destroys the glomerular basement membrane and epithelial cell membrane barrier, interferes with the synthesis of nephrin and other molecules in podocytes, resulting in a large amount of proteinuria [2]. The model shows chronic progression of renal injury, that is, its early manifestation is foot process effacement, followed by progressive renal injury such as extensive glomerular lesion, tubular dilatation and interstitial fibrosis, manifested as pathological features of focal segmental glomerulus sclerosis (FSGS) [3]. Ursolic Acid (UA) is a pentacyclic triterpenoid compound widely found in natural plants, with sedative, anti-inflammatory, hypoglycemic, anti-oxidation and many other biological effects. Also, it has a good inhibitory effect on various cancer cell models such as lung cancer, liver cancer, pancreatic cancer and breast cancer [4]. In this experiment, we attempt to establish a nephropathy model by injecting adriamycin into the mice via tail vein to explore the protective mechanism of ursolic acid on the renal injury.

\section{Materials and Methods}

\subsection{Materials}

\subsubsection{Animals}

A total of 40 adult healthy male Balb/c mice, weighing $25 \pm 2 \mathrm{~g}$, were purchased from Hubei Animal Experimental Center. License No.: SCXK (E) 2015-0018, experimental animal qualification No.: No. 42000600027264. This experiment has been reviewed and approved by the Experimental Animal Ethics Review Committee of the Yangtze University Health Science Center. The disposal of animals during the experiment complies with the relevant standards of the International Animal Ethics Association.

\subsubsection{Reagent and Instrument}

Ursolic acid was purchased from Sigma, USA; BCA protein assay kit was purchased from Shanghai Beyotime Biotechnology Co., Ltd.; BUN, SCR, TG, SOD, MDA, GSH assay kits were purchased from Nanjing Institute of Bioengineering; tumor necrosis factor- $\alpha$ (TNF- $\alpha$ ), interleukin- $1 \beta$ (IL-1 $\beta$ ), transforming growth factor- $\beta 1$ (TGF- $\beta 1$ ) assay kits (ELISA method) were purchased from Roche, Germany. SMAD3, SMAD2, GAPDH, $\alpha$-smooth muscle actin ( $\alpha$-SMA) primary antibody (Abcam, Cambridge) and secondary antibody (Cell signaling Tec); G250 coomassie brilliant blue assay kit (Xiamen Taijing Biotechnology Co., Ltd.); vertical electrophoresis unit, film transfer unit (Bio-Rad, Hercules, CA, USA); automatic biochemical analyzer (HITACHI, Japan, 7600-020); UV visible spectrophotometer (SHIMADZU, Japan, UV-1700).

\subsection{Methods}

\subsubsection{Grouping and Administration}

A total of 40 adult healthy male Balb/c mice were acclimated for 1week in the laboratory and randomly divided into 4 groups, namely normal group, model group, low dose of UA group ( $25 \mathrm{mg} / \mathrm{kg} / \mathrm{d}$ ) and high dose of UA group (50 
$\mathrm{mg} / \mathrm{kg} / \mathrm{d}), 10$ for each group. Except that the same amount of normal saline was injected into the mice via the tail vein in the normal group, ADR was injected into the mice via the tail vein in the remaining groups at $10 \mathrm{mg} / \mathrm{kg}$ to establish the models [5] [6]. After 1 week of administration, the $24 \mathrm{~h}$ urine was collected from the metabolic cage for the urine protein quantification. From the first day after successful modeling, different doses of UA were administered to the mice in the treatment group, and the UA dose referred to the determination of blood concentration [7]. The mice in the normal group and the model group were administered with the same amount of normal saline at $10 \mathrm{mg} / \mathrm{kg} / \mathrm{d}$, once per day for consecutive 3 weeks.

\subsubsection{Quantification of the 24-Hour Urine Protein}

After the successful modeling of ADR, the $24 \mathrm{~h}$ urine before administration and at the end of the first week, second week and third week after administration was collected from the metabolic cage. The total amount of $24 \mathrm{~h}$ urine protein was measured according to the instructions of G250 coomassie blue assay kit.

\subsubsection{Determination of Biochemical Indices}

Six hours after the last administration on the 18th day, the mouse eyeballs were taken for whole blood, the serum was separated according to the method labeled on the kit and the BUN, Scr and TG were measured by the automatic biochemical analyzer. The mice were sacrificed by cervical dislocation. Some left kidney tissues were taken along the midline of the abdomen and then washed with cold saline to prepare $10 \%$ tissue homogenate. The SOD, MDA and GSH were determined by WST-1 method, TBA method and micro-plate test, respectively. The procedure was conducted in strict accordance with the instruction of the kits which were purchased from Nanjing Jiancheng Bioengineering Institute of China.

\subsubsection{Determination of TNF- $\alpha$, IL- $1 \beta$, TGF- $\beta 1$}

Some of kidney tissue cell lysate was fully homogenized, processed in ice bath and then using high-speed centrifugation. The supernatant was taken for protein quantitation, and TNF- $\alpha$, IL- $1 \beta$, IL- 6 were measured using enzyme-linked immunosorbent assay (ELISA).

\subsubsection{Pathological Observation of Kidney Tissue}

The fresh right kidney tissue was taken and fixed with $4 \%$ neutral formaldehyde, dehydrated with gradient alcohol, cleared with xylene, embedded in paraffin, sectioned and stained by H.E, and observed under the optical microscope.

\subsubsection{Western Blot}

The total protein was extracted from the kidney tissue. The concentration of the protein sample was measured using bisquinolinecarboxylic acid (BCA) method. The protein sample was separated by SDS-polyacrylamide gel electrophoresis, processed using PVDF transfer film (Piece, USA), closed in 5\% skim milk powder for 1 hour, incubated overnight in primary antibody at $4^{\circ} \mathrm{C}$, washed with 
TBST, incubated in HRP-labeled secondary antibody at room temperature for 1 hour and washed with TBST. Taking GAPDH as internal control, the ECL enhanced luminescence kit was used for protein signal detection. The Quantity One software was used to analyze the SMAD3, SMAD2, $\alpha$-SMA band integrated optical density, and the ratios of the target strip integrated optical densities to the internal control integrated optical density were used as the semi-quantitative results of the protein expression in the corresponding lanes.

\subsection{Statistical Analysis}

Statistical analysis was performed using SPSS 13.0 software (Statistical Product and Service Solutions, IBM, USA). The data were represented by $\bar{\chi} \pm$ s. The comparison between groups was analyzed by ANOVA and $\mathrm{P}<0.05$ was considered statistically significant.

\section{Results}

\subsection{Quantification of $24 \mathrm{~h}$ Urine Protein}

After 1 week of the administration to the ADR model groups, the urine protein of each group was equal or greater than $30 \mathrm{mg} / \mathrm{kg} \cdot \mathrm{d}$ except for the normal group, indicating that the model was successfully prepared. Compared with the normal group, the $24 \mathrm{~h}$ urine protein in the model group continued to increase and the difference was significant $(\mathrm{P}<0.05)$. After the $\mathrm{UA}$ treatment, the $24 \mathrm{~h}$ urine protein significantly decreased $(\mathrm{P}<0.05)$. See Table 1 .

\subsection{Effects of UA on Biochemical Indices of Mice}

After the administration to the ADR model groups, compared with the normal group, the BUN, Scr and TG in the model group significantly increased, the MDA in the kidney issue homogenate significantly increased, and the GSH and SOD significantly decreased. Compared with the model group, the above biochemical indices in the low and high dose of UA groups showed opposite changes. The difference was statistically significant $(\mathrm{P}<0.05)$. There was a certain dose-dependent trend within the experiment. See Table 2.

Table 1. Effects of UA on $24 \mathrm{~h}$ urine protein quantification of the mice in each group $(\bar{\chi}$ $\pm \mathrm{s}, \mathrm{n}=10$ ).

\begin{tabular}{|c|c|c|c|c|c|}
\hline & $\begin{array}{c}\text { Dose } \\
\left(\mathrm{mg} \cdot \mathrm{kg}^{-1}\right)\end{array}$ & $\begin{array}{l}\text { Number of } \\
\text { the mice }(n)\end{array}$ & $\begin{array}{c}\text { 1W UTP } \\
\left(\mathrm{mg} \cdot \mathrm{day}^{-1}\right)\end{array}$ & $\begin{array}{l}\text { 2W UTP } \\
\left(\mathrm{mg} \cdot \text { day }^{-1}\right)\end{array}$ & $\begin{array}{l}\text { 3W UTP } \\
\left(\mathrm{mg} \cdot \mathrm{day}^{-1}\right)\end{array}$ \\
\hline Normal group & & 10 & $6.35 \pm 0.35$ & $6.42 \pm 0.17$ & $6.55 \pm 0.18$ \\
\hline Model group & & 10 & $38.68 \pm 2.06 a$ & $42.79 \pm 1.22 \mathrm{a}$ & $49.79 \pm 1.36 \mathrm{a}$ \\
\hline Low dose of UA & 25 & 10 & $35.12 \pm 1.47 \mathrm{a}$ & $31.47 \pm 1.78 \mathrm{ab}$ & $28.08 \pm 0.78 \mathrm{ab}$ \\
\hline High dose of UA & 50 & 10 & $33.26 \pm 1.25 \mathrm{a}$ & $26.28 \pm 1.45 \mathrm{ab}$ & $21.28 \pm 0.45 \mathrm{ab}$ \\
\hline
\end{tabular}

Note: Compared with the normal group: ${ }^{a} \mathrm{P}<0.05$; compared with the model group: ${ }^{b} \mathrm{P}<0.05$; the same as following tables. 
Table 2. Effects of UA on biochemical indices of the mice in each group $(\bar{\chi} \pm \mathrm{s}, \mathrm{n}=10)$.

\begin{tabular}{cccccccc}
\hline \multirow{2}{*}{$\begin{array}{c}\mathrm{n}=10) \\
\left(\mathrm{mg} \cdot \mathrm{kg}^{-1}\right)\end{array}$} & $\begin{array}{c}\mathrm{BUN} \\
\left(\mathrm{mmol} \cdot \mathrm{L}^{-1}\right)\end{array}$ & $\begin{array}{c}\mathrm{Scr} \\
\left(\mu \mathrm{mol} \cdot \mathrm{L}^{-1}\right)\end{array}$ & $\begin{array}{c}\mathrm{TG} \\
\left(\mathrm{mmol} \cdot \mathrm{L}^{-1}\right)\end{array}$ & $\begin{array}{c}\mathrm{MDA} \\
\left(\mathrm{nmol} \cdot \mathrm{mg}^{-1}\right)\end{array}$ & $\begin{array}{c}\mathrm{GSH} \\
\left(\mathrm{nmol}^{\mathrm{m}} \mathrm{mg}^{-1}\right)\end{array}$ & $\begin{array}{c}\text { SOD } \\
\left(\mathrm{U} \cdot \mathrm{mg}^{-1}\right)\end{array}$ \\
\hline Normal group & & $8.42 \pm 1.37$ & $51.33 \pm 11.25$ & $0.85 \pm 0.14$ & $1.39 \pm 0.22$ & $30.63 \pm 2.52$ & $0.98 \pm 0.14$ \\
& & $23.31 \pm 2.24 \mathrm{a}$ & $262.28 \pm 38.15 \mathrm{a}$ & $4.28 \pm 0.41 \mathrm{a}$ & $4.26 \pm 0.51 \mathrm{a}$ & $16.12 \pm 1.05 \mathrm{a}$ & $0.39 \pm 0.11 \mathrm{a}$ \\
Model group & & $15.63 \pm 1.15 \mathrm{ab}$ & $165.51 \pm 27.18 \mathrm{ab}$ & $2.96 \pm 0.24 \mathrm{ab}$ & $3.16 \pm 0.42 \mathrm{ab}$ & $22.31 \pm 1.14 \mathrm{ab}$ & $0.56 \pm 0.14 \mathrm{ab}$ \\
Low dose of UA & 25 & $12.18 \pm 1.44 \mathrm{ab}$ & $96.55 \pm 23.38 \mathrm{ab}$ & $1.43 \pm 0.44 \mathrm{ab}$ & $2.28 \pm 0.53 \mathrm{ab}$ & $26.85 \pm 1.36 \mathrm{ab}$ & $0.78 \pm 0.15 \mathrm{ab}$ \\
High dose of UA & 50 & & &
\end{tabular}

Note: $\mathrm{BUN}=$ blood urine nitrogen, $\mathrm{Scr}=$ serum creatinine, $\mathrm{TG}=$ triglyceride, $\mathrm{MDA}=$ malondialdehyde, $\mathrm{GSH}=$ glutathione, $\mathrm{SOD}=$ superoxide dismutase.

\subsection{Effects of UA on TNF- $\alpha$, IL- $1 \beta$ and TGF- $\beta 1$ in Mice}

Compared with the normal group, the TNF- $\alpha$, IL- $1 \beta$ and TGF- $\beta 1$ in the model group significantly increased, and the difference was statically significant $(\mathrm{P}<$ 0.05). Compared with the model group, the measured indices in the low and high dose of UA groups also showed opposite changes. The difference was statistically significant, too. There was a certain dose-dependent trend within the experiment. See Table 3.

\subsection{Pathological Changes of Renal Tissues}

Compared with the normal group, some glomerular capillary loops of the mice in the model group collapsed and shrunk, and the periphery of the glomerulus was attached to the renal balloon. The mesangial matrix widened and thickened and the mesangial cells proliferated. Some of the renal tubules shrunk, accompanied by obvious vacuolar degeneration and protein cast formation. There was infiltration by large amount of inflammatory cells, mainly lymphocytes, mixed with a small number of neutrophils. Compared with the model group, the pathological injury of the mice in the low dose of UA group was not significantly improved under the optical microscope, while the number of inflammatory cells in the renal interstitium of the mice decreased in the high dose of UA group, the adhesion to the renal balloon was reduced. The vacuolar degeneration was still present in some of the renal tubular epithelial cells, but the injury was significantly reduced, and the number of protein casts decreased. See Figure 1.

\subsection{Effects of UA on SMAD2/3 Phosphorylation and $\alpha$-SMA Expression in Mouse Renal Tissues}

Compared with the control group, the SMAD2/3 phosphorylation and the SMAD3 target protein $\alpha$-SMA expression in the ADR nephropathy model group significantly increased $(\mathrm{P}<0.05)$. Also, compared with the model group, after treatment with $\mathrm{UA}$, the SMAD2/3 phosphorylation was significantly reduced while the $\alpha$-SMA expression markedly increased, and the expression gradually increased with the increase of the UA dose. The difference was significant $(\mathrm{P}<$ 0.05). See Table 4 and Figure 2. 


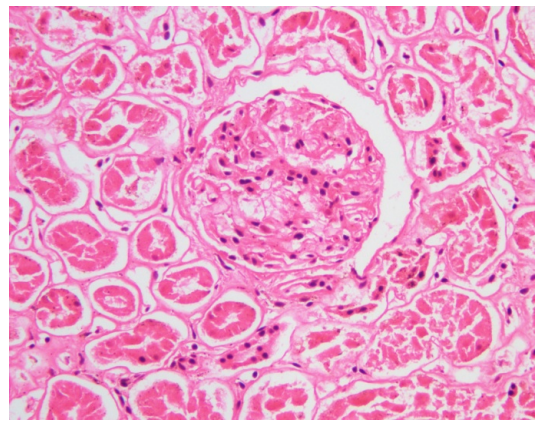

(a)

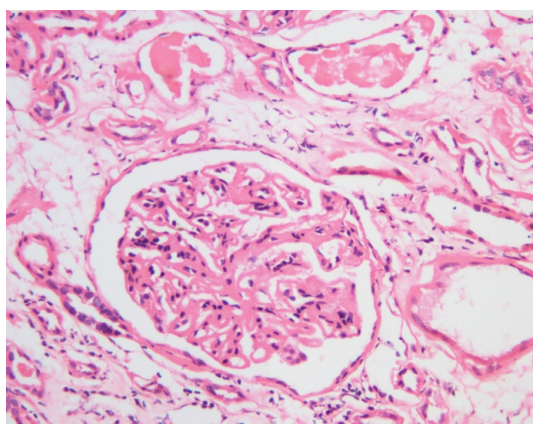

(c)

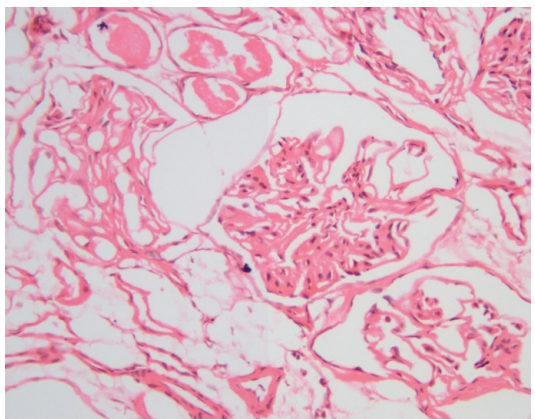

(b)

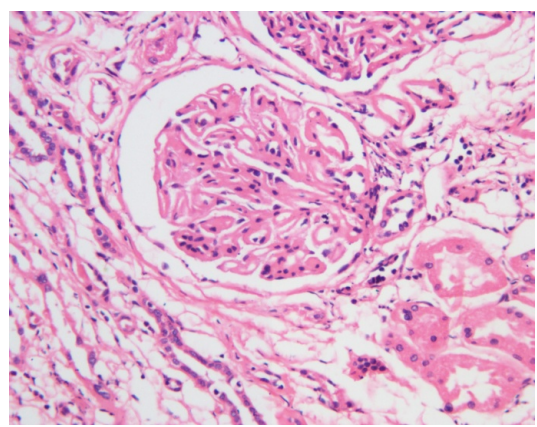

(d)

Figure 1. Effects of UA on pathological changes of renal tissues in mice. (a) Normal group; (b) Model group; (c) low dose of UA; (d) High dose of UA.

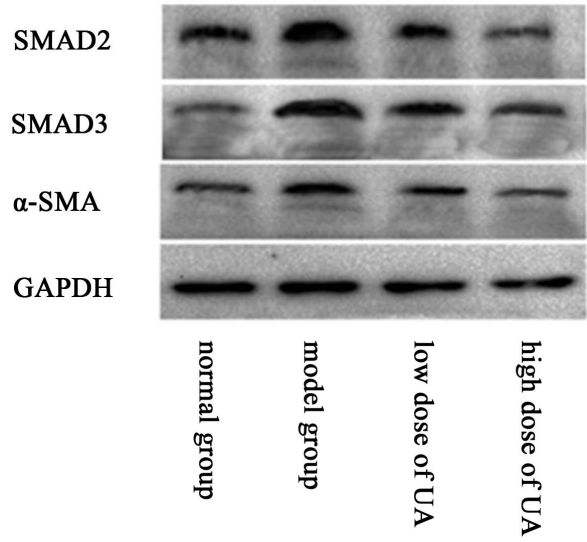

Figure 2. Western blot results.

Table 3. Effects of UA on TNF- $\alpha$, IL- $1 \beta$ and TGF- $\beta$ in mice in each group $(\bar{\chi} \pm \mathrm{s}, \mathrm{n}=$ $10)$.

\begin{tabular}{ccccc}
\hline (n=10) & $\begin{array}{c}\text { Dose } \\
\left(\mathrm{mg} \cdot \mathrm{kg}^{-1}\right)\end{array}$ & $\begin{array}{c}\mathrm{TNF}-\alpha \\
\left(\mathrm{pg} \cdot \mathrm{mg}^{-1}\right)\end{array}$ & $\begin{array}{c}\mathrm{IL}-1 \beta \\
\left(\mathrm{pg} \cdot \mathrm{mg}^{-1}\right)\end{array}$ & $\begin{array}{c}\mathrm{TGF}-\beta \\
\left(\mathrm{pg} \cdot \mathrm{mg}^{-1}\right)\end{array}$ \\
\hline Normal group & & $53.33 \pm 8.15$ & $72.12 \pm 11.25$ & $64.35 \pm 10.14$ \\
model group & & $153.28 \pm 18.04 \mathrm{a}$ & $212.33 \pm 27.65 \mathrm{a}$ & $284.72 \pm 18.37 \mathrm{a}$ \\
Low dose of UA & 25 & $113.86 \pm 20.25 \mathrm{ab}$ & $172.51 \pm 21.25 \mathrm{ab}$ & $195.46 \pm 17.63 \mathrm{ab}$ \\
High dose of UA & 50 & $88.44 . \pm 20.43 \mathrm{ab}$ & $133.47 \pm 22.42 \mathrm{ab}$ & $161.28 \pm 17.34 \mathrm{ab}$ \\
\hline
\end{tabular}

Note: TNF- $\alpha=$ tumor necrosis factor- $\alpha$, IL- $1 \beta=$ interleukin- $1 \beta$, TGF- $\beta=$ transforming growth factor- $\beta$. 
Table 4. Effects of UA on SMAD2/3 phosphorylation and $\alpha$-SMA expression in mice in each group $(\bar{\chi} \pm \mathrm{s}, \mathrm{n}=10)$.

\begin{tabular}{ccccc}
\hline (n $=10)$ & $\begin{array}{c}\text { Dose } \\
\left(\mathrm{mg} \cdot \mathrm{kg}^{-1}\right)\end{array}$ & $\begin{array}{c}\text { SMAD2 } \\
\left(\mathrm{pg} \cdot \mathrm{mg}^{-1}\right)\end{array}$ & $\begin{array}{c}\text { SMAD3 } \\
\left(\mathrm{pg} \cdot \mathrm{mg}^{-1}\right)\end{array}$ & $\begin{array}{c}\alpha-\mathrm{SMA} \\
\left(\mathrm{pg} \cdot \mathrm{mg}^{-1}\right)\end{array}$ \\
\hline Normal group & & $1.03 \pm 0.08$ & $0.91 \pm 0.08$ & $0.27 \pm 0.04$ \\
Model group & & $2.25 \pm 0.14 \mathrm{a}$ & $2.37 \pm 0.13 \mathrm{a}$ & $2.02 \pm 0.17 \mathrm{a}$ \\
Low dose of UA & 25 & $1.89 \pm 0.11 \mathrm{ab}$ & $1.78 \pm 0.12 \mathrm{ab}$ & $1.73 \pm 0.13 \mathrm{ab}$ \\
High dose of UA & 50 & $1.65 \pm 0.15 \mathrm{ab}$ & $1.57 \pm 0.18 \mathrm{ab}$ & $1.66 \pm 0.18 \mathrm{ab}$ \\
\hline
\end{tabular}

Note: $\alpha$-SMA $=\alpha$-smooth muscle actin.

\section{Discussion}

$\mathrm{ADR}$ is an anti-tumor antibiotic containing a quinoid structure that can be reduced to a semi-quinone radical by metabolism in the kidney. The semi-quinone radical reacts with oxygen to produce reactive oxygen species which induces lipid peroxidation in glomerular epithelial cells, thereby disrupting the structure and function of the filter membrane and and ultimately leading to proteinuria [2]. The acute AN model is caused by a single tail vein injection of doxorubicin, which has been widely used in the experimental study of nephrotic syndrome by domestic and foreign scholars based on its ability to effectively stimulate human MCD [1]. In this experiment, the method was used for modeling. After 1 week, the urine protein of each group was equal or greater than $30 \mathrm{mg} / \mathrm{kg} \cdot \mathrm{d}$ except for the normal group, indicating that the model was successfully prepared. And compared with the normal group, the $24 \mathrm{~h}$ urine protein quantification in the model group continued to increase with the time. At the end of the third week, the symbolic index BUN and Scr for detecting renal function significantly increased, the serum TG also significantly increased, and renal tissues had obvious pathological changes, suggesting that the renal lesion continued to increase, the blood lipid increased and the renal function was impaired.

Oxidative stress plays a crucial role in promoting the production of podocyte injury, glomerular sclerosis and proteinuria [8]. SOD is an important antioxidant enzyme that repairs cells in time and inhibits cellular damage caused by oxygen free radicals [9]. GPx is another important antioxidant protein and its active center, selesnocysteine, can catalyze the conversion of GSH to GSSG, that is, it can reduce toxic peroxides to non-toxic bydroxy compounds, thereby protecting the structure and function of cell membranes. The abnormal SOD and GPx expression are closely related to renal injury caused by ADR [10] [11]. $\mathrm{MDA}$ is one of the important metabolites in the process of membrane lipid peroxidation. In the study of kidney protection, the degree of membrane lipid peroxidation can be understood by MDA content, which is used to evaluate the degree of cell membrane damage indirectly [12]. This study found that compared with the model group, ursolic acid can reduce the MDA, increase the SOD and GPx activity, and attenuate the mouse renal injury caused by adriamycin through inhibiting mitochondrial reactive oxygen species production or an- 
ti-oxidative damage. The efficacy was significantly enhanced with the increase of the dose within the experiment.

ADR can directly destroy the natural cells of the kidney after entering the blood circulation and induces the inflammation, leading to the continuous progression of AN and then the end-stage renal disease. P38 mitogen-activated protein kinase (MAPK) plays an important role in the formation of AN inflammation. Activated p38 MAPK can induce the secretion and production of pro-inflammatory cytokines TNF- $\alpha$ and IL- $1 \beta$, while TNF- $\alpha$ and IL- $1 \beta$ can enhance p38 MAPK activity through autocrine and paracrine, promote AN inflammatory response and increases glomerular damage [13] [14]. The macrophages, monocytes and mesangial cells activated by ADR during the destruction of glomerular filtration barrier by cytotoxicity can also induce TNF- $\alpha$ and IL-1 $\beta$, and promote the Epithelial-Mesenchymal Transition (EMT) and the production of extracellular matrix (ECM), which which alters the structure and function of the kidney and promotes the progression of renal fibrosis (RF) [15]. The protective effect of ursolic acid on doxorubicin nephropathy has been reported in the literature, but the effect of ursolic acid on inflammatory factors have not been discussed in depth. This study showed that the UA treatment can significantly reduce the expression of TNF- $\alpha$ and IL- $1 \beta$ in mice with AN and is consistent with the improvement of renal function and renal pathomorphology, indicating that UA can affect TNF- $\alpha$ and IL- $1 \beta$ expression, improve the inflammation in mice with AN, improve the degree of RF and attenuate glomerular lesion. The efficacy was significantly enhanced with the increase of the dose within the experiment.

$\mathrm{RF}$ is a common pathway for all progressive nephropathy, while TGF- $\beta 1$ / Smads is considered to be one of the classical RF pathways. TGF- $\beta 1$ is mainly distributed in glomerular and tubular epithelial cells and is an important factor in RF. Smads is a downstream signal transduction protein of TGF- $\beta$, and Smad $2 / 3$ is a major player in TGF- $\beta 1$-mediated cell transduction pathway from the cell membrane to the nucleus. The degree of phosphorylation reflects the activation of TGF- $\beta$ signaling pathway and the transcriptional level of downstream target proteins [16] [17]. Currently, the role of TGF-1/Smads related signaling pathway in the discussion of the protective mechanism of ursolic acid against doxorubicin nephropathy has not been deeply involved in the existing literature. Recent studies have shown that Smad2 phosphorylation is not significantly associated with RF, whereas Smad3 phosphorylation is significantly associated with $\mathrm{RF}$ [18]. In this experiment, the Smad3 expression increased in the model group, but UA down-regulated the Smad3 expression after intervention, suggesting that UA can interfere with the RF process by affecting Smad3 phosphorylation and then inhibiting TGF- $\beta$ signaling pathway. $\alpha$-SMA is one of the major markers of ECM and activated fibroblasts in RF, as well as the main target gene of TGF- $\beta$, but also is a damage index of tubulointerstitial fibrosis [19] [20]. This experiment showed that UA could significantly down-regulate the $\alpha$-SMA expression in mice with AN, thereby inhibiting the transition of myofibroblasts and reduc- 
ing the tubulointerstitial fibrosis in mice with AN.

\section{Conclusion}

In summary, ursolic acid can protect against adriamycin nephropathy in mice, which mechanism may be related to the inhibition of TGF-1/Smads-related signaling pathway, the inhibition of oxidative stress, the reduction of inflammatory cytokines release, and the inhibition of or delay in renal tubule-interstitial fibrosis. The efficacy was significantly enhanced with the increase of the dose within the experiment. The dosage, blood concentration and adverse reactions of ursolic acid are not clear yet, therefore, its effectiveness and safety need to be further studied in future.

\section{Conflicts of Interest}

The authors declare no conflict of interest regarding the publication of this paper.

\section{References}

[1] Li, J.S., Chen, X., Peng, L., et al. (2015) Angiopoietin-Like-4, a Potential Target of Tacrolimus, Predicts Earlier Podocyte Injury in Minimal Change Disease. PLoS ONE, 10, e0137049. https://doi.org/10.1371/journal.pone.0137049

[2] Bertani, T., Poggi, A., Pozzoni, R., et al. (1982) Adriamycin-Induced Nephrotic Syndrome in Rats: Sequence of Pathologic Events. Laboratory Investigation, 46, 16-23.

[3] Bertelli, R., Bonanni, A., Caridi, G., et al. (2018) Molecular and Cellular Mechanisms for Proteinuria in Minimal Change Disease. Frontiers in Medicine (Lausanne), 5, 170. https://doi.org/10.3389/fmed.2018.00170

[4] López-Hortas, L., Pérez-Larrán, P., González-Muñoz, M.J., et al. (2018) Recent Developments on the Extraction and Application of Ursolic Acid. A Review. Food Research International, 103, 130-149. https://doi.org/10.1016/j.foodres.2017.10.028

[5] Lui, S.L., Tsang, R., Chan, K.W., et al. (2009) Rapamycin Attenuates the Severity of Murine Adriamycin Nephropathy. American Journal of Nephrology, 2, 342-352. https://doi.org/10.1159/000166599

[6] Liu, G., Tang, L., She, J., et al. (2018) Alpha-Mangostin Attenuates Focal Segmental Glomerulosclerosis of Mice Induced by Adriamycin. Journal of Central South University. Medical Sciences, 43, 1089-1096.

[7] Liao, Q., Yang, W., Jia, Y., et al. (2005) LC-MS Determination and Pharmacokinetic Studies of Ursolic Acid in Rat Plasma after Administration of the Traditional Chinese Medicinal Preparation Lu-Ying Extract. Yakugaku Zasshi, 125, 509-515. https://doi.org/10.1248/yakushi.125.509

[8] Tan, R.J., Zhou, D., Xiao, L., et al. (2015) Extracellular Superoxide Dismutase Protects against Proteinuric Kidney Disease. Journals of the American Society of Nephrology, 26, 24-47. https://doi.org/10.1681/ASN.2014060613

[9] Broxton, C.N. and Culotta, V.C. (2016) SOD Enzymes and Microbial Pathogens: Surviving the Oxidative Storm of Infection. PLOS Pathogens, 12, e1005295. https://doi.org/10.1371/journal.ppat.1005295

[10] Brigelius-Flohé, R., Müller, C., Menard, J., et al. (2001) Functions of GI-GPx: Les- 
sons from Selenium-Dependent Expression and Intracellular Localization. Biofactors, 14, 101-106. https://doi.org/10.1002/biof.5520140114

[11] Qin, X.J., He, W., Hai, C.X., et al. (2008) Protection of Multiple Antioxidants Chinese Herbal Medicine on the Oxidative Stress Induced by Adriamycin Chemotherapy. Journal of Applied Toxicology, 28, 271-282. https://doi.org/10.1002/jat.1276

[12] Peng, C.C., Hsieh, C.L., Wang, H.E., et al. (2012) Ferulic Acid Is Nephrodamaging While Gallic Acid Is Renal Protective in Long Term Treatment of Chronic Kidney Disease. Clinical Nutrition, 31, 405-414. https://doi.org/10.1016/j.clnu.2011.11.003

[13] Furuichi, K., Wada, T., Iwata, Y., et al. (2002) Administration of FR167653, a New Anti-Inflammatory Compound, Prevents Renal Ischaemia/Reperfusion Injury in Mice. Nephrology Dialysis Transplantation, 17, 399-407. https://doi.org/10.1093/ndt/17.3.399

[14] Li, J., Campanale, N.V., Liang, R.J., et al. (2006) Inhibition of p38 Mitogen-Activated Protein Kinase and Transforming Growth Factor- $\beta 1 /$ Smad Signaling Pathways Modulates the Development of Fibrosis in Adriamycin-Induced Nephropathy. The American Journal of Pathology, 169, 1527-1540. https://doi.org/10.2353/ajpath.2006.060169

[15] Falke, L.L., Gholizadeh, S., Goldschmeding, R., et al. (2015) Diverse Origins of the Myofibroblast-Implications for Kidney Fibrosis. Nature Reviews Nephrology, 11, 233-244. https://doi.org/10.1038/nrneph.2014.246

[16] Sutariya, B., Jhonsa, D. and Saraf, M.N. (2016) TGF- $\beta$ : The Connecting Link between Nephropathy and Fibrosis. Immunopharmacology and Immunotoxicology, 38, 39-49. https://doi.org/10.3109/08923973.2015.1127382

[17] Greene, I. (2015) Kaempferol and Esculetin as Potential Therapeutic Agents in Chronic Renal Allograft Injury. Mount Sinai: Icahn School of Medicine, New York.

[18] Baumann, B., Hayashida, T., Liang, X., et al. (2016) Hypoxia-Inducible Factor-1 $\alpha$ Promotes Glomerulosclerosis and Regulates COL1A2 Expression through Interactions with Smad3. Kidney International, 90, 797-808. https://doi.org/10.1016/j.kint.2016.05.026

[19] Jia, L., Ma, X., Gui, B., et al. (2015) Sorafenib Ameliorates Renal Fibrosis through Inhibition of TGF- $\beta$-Induced Epithelial-Mesenchymal Transition. PLoS ONE, 10, e0117757. https://doi.org/10.1371/journal.pone.0117757

[20] Hu, B., Wu, Z. and Phan, S.H. (2003) Smad3 Mediates Transforming Growth Factor-Beta-Induced Alpha-Smooth Muscle Actin Expression. American Journal of Respiratory Cell and Molecular Biology, 29, 397-404. https://doi.org/10.1165/rcmb.2003-0063OC 